\author{
Robert Konieczka \\ Dr inż. \\ Katedra Logistyki i Technologii \\ Lotniczych Wydziału Transportu \\ Politechniki Śląskiej \\ robert.konieczka@polsl.pl
}

DOI: 10.35117/A_ENG_18_01_02

\title{
Defines causes and the circumstance of air accidents in preparatory conducts connected with their appearing
}

\begin{abstract}
Article makes up the attempt of the synthetic formulation of the causes of air accident which necessary to fix during preparatory proceding, and then judicial. It should notice that the proper qualification of causes and the circumstance of the air accident or different event, has to show possible guilty persons in the led conduct and qualify the range of contributing their to the rise of the event. Indicated rasons can be differ than essential way of diagnose by the State Committee of Investigation Air Accidents. It is results of the procedure distinction and also divergent goal. These questions will be analysed through the general causes of occurrence of air accident and their source.
\end{abstract}

Keywords: Cause of an air accident; Air accident; Iinvestigation of the causes of the accident

\section{Introduction}

Determining the cause of an aircraft accident is a key goal that all aviation event authorities pursue. This applies first of all to national bodies investigating aviation accidents, (in Poland, the State Commission on Aircraft Accident Investigation) which, under the regulations in force in this respect, are obliged to determine the causes of aviation accidents and incidents in order to prevent their occurrence. Distinct bodies dealing with determining the causes of the accident are prosecution and police bodies, as well as courts. Their basic task is to determine if a crime has occurred in connection with the occurrence of an aviation accident. In the longer term, this results in the indication of persons possibly responsible for the accident and determining their fault. The proceedings conducted by the PKBWL and the statutory public security and justice bodies are separate in nature due to their goals and are carried out independently of each other. As will be indicated later in the article, the determination of the causes of the accident is only an intermediate goal for the latter.

\section{Statistical causes of air accidents}

The estimation of the causes of aviation accidents is the easiest to present in a statistical form. The literature on the subject contains many different statistics on the causes of accidents, which cannot be described here. At the same time, it should be noted that they will vary depending on various factors such as period, type of aviation (civil/military), types of aircraft, nature of tasks performed, etc. Detailed analysis of so many factors determining the diversity of causes of accidents goes far beyond the scope of this study. Nevertheless, on the basis of the statistics presented below, it is possible to indicate general regularities useful for further considerations.

Figures 1 and 2 present selected examples of statistics on the general causes of aviation accidents concerning, respectively, civil and military aviation [8],[5]. Despite many important differences between these two air systems, the causes of aviation events are arranged in accordance with similar regularities. Apart from various percentages, it should be 
noted that the main cause of events is the broadly understood human factor. Air technology is in second place. Finally, further extensive organizational factors. However, already from the very content of the reasons indicated in Figure 1, as well as other sources not quoted here, it follows that these causes do not have a homogeneous background. This issue is illustrated on the basis of [4] chart in Figure 3 based on [8]. For the purpose of detecting sources of threats in civil air transport, the reports of the State Commission on Aircraft Accident Investigation in 2015 were analyzed there. Among the analyzed events, an analysis of threats and their sources was made, illustrating this with the graph shown in Figure 3.

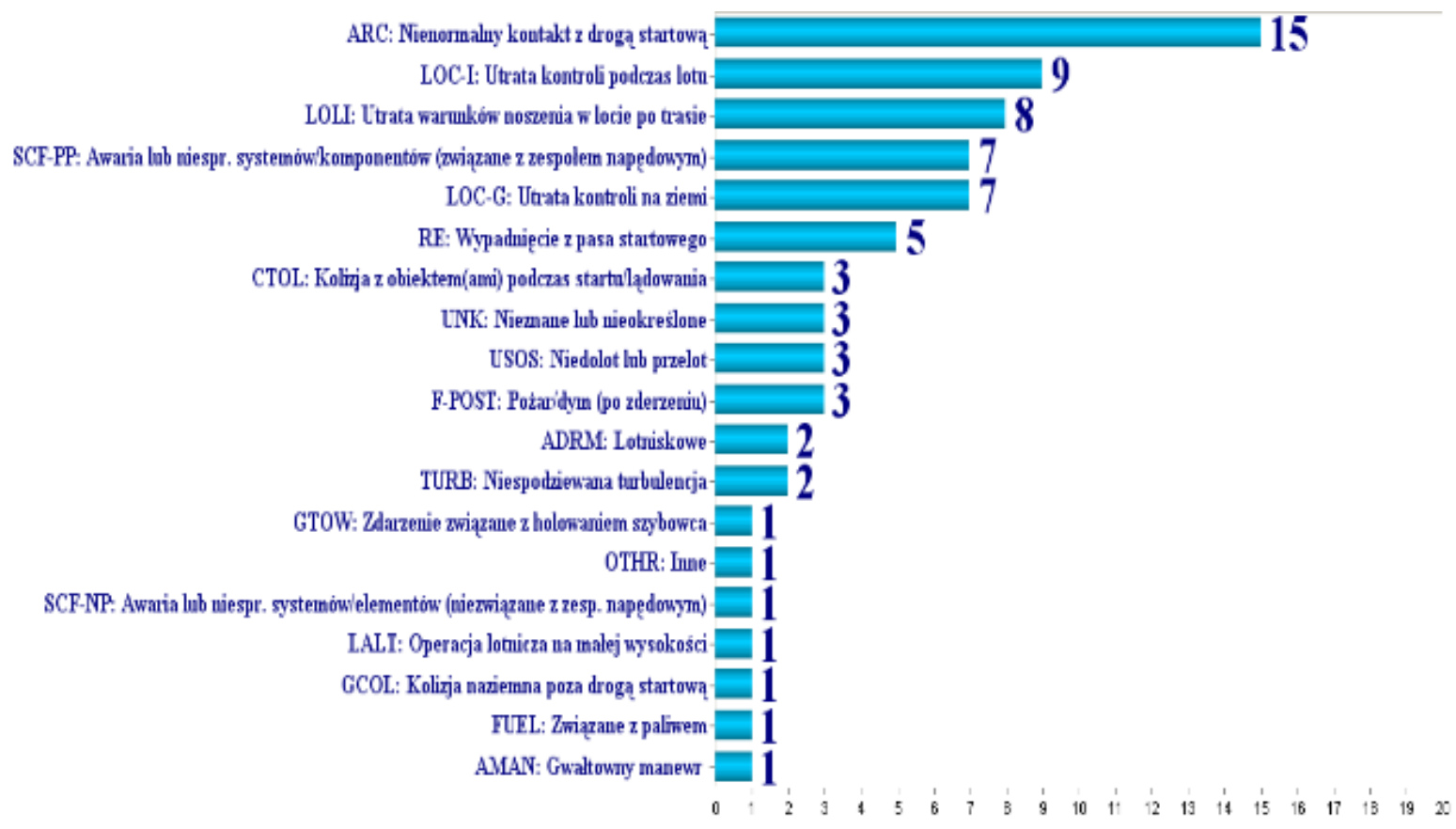

1. Categories of ICAO aviation incidents occurred in 2010 [5]

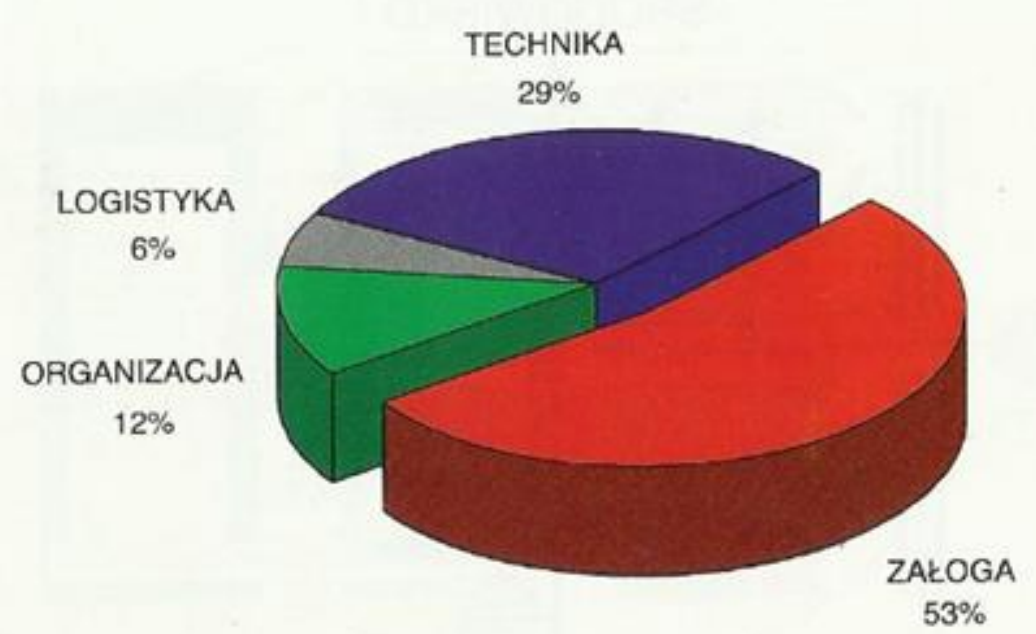

2. The distribution of causes of air accidents at the aviation school in Dęblin (depending on the year of WOSL and WSOSP) for the years 1986 -19950 [8] 


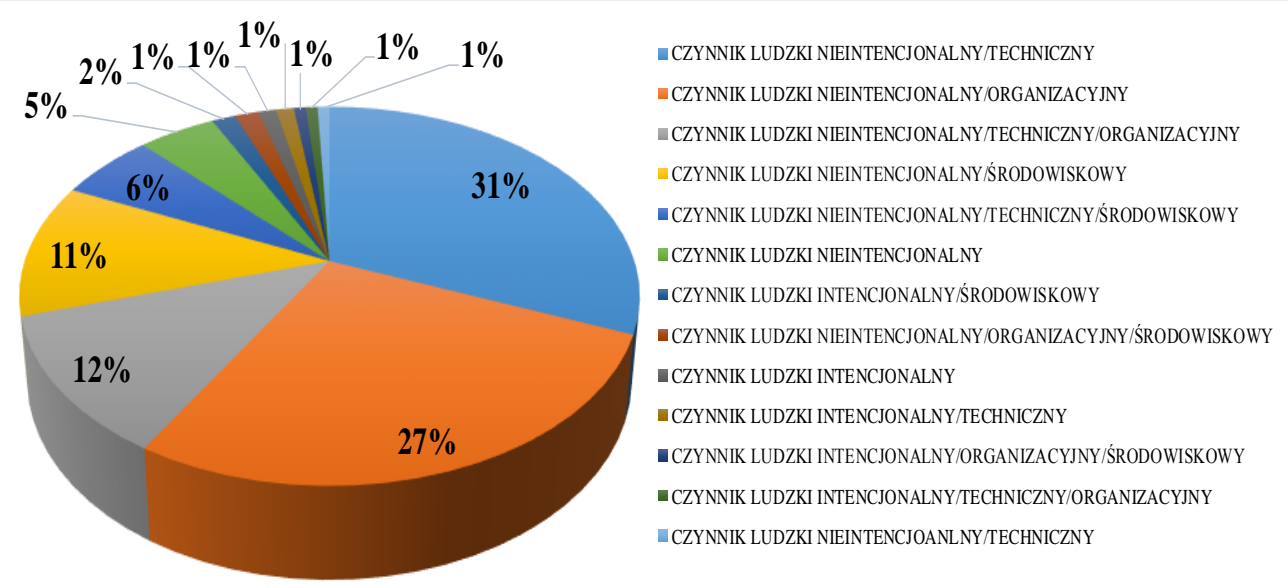

3. The percentage share of threat groups determining aviation events in 2015 [4].

These statistics confirm the identification of constantly occurring groups of threat sources - the human factor in combination with other areas of threats. The vast majority of events originated from unintentional activities and only in very few cases there were intentional factors (5\% of all events). In the analyzed events, their assessment was too general, which did not allow a full analysis of the sources and their evaluation. Even more detailed relevant causes of accidents are indicated below on the basis of [3] indicated below with their percentage share:

- non-observance of basic operational procedures by the crew - 33\%,

- inadequate verification of activities by other crew members $-26 \%$,

- design errors - $13 \%$.

- deficiencies in technical service and ground control - $12 \%$,

- lack of homing during the approach to landing $-10 \%$,

- ignoring the crew's remarks by the captain - $10 \%$,

- errors or mistakes in air traffic control - 9\%,

- improper operation of the crew in unusual conditions $-9 \%$,

- incorrect or insufficient meteorological information - 8\%,

- problems on the runway - $7 \%$,

- air traffic control communication problems - 6\%,

- wrong decision when landing $-6 \%$.

The above list presents a broad spectrum of identified causes. However, it is not difficult to notice that human errors are dominant here. In particular, this list illustrates the hazards resulting from cooperation in the crew.

\section{Human activities as the primary causes of aviation accidents}

Human activities constituting the main aspect of the human factor should be understood here in a multifaceted manner. The key element is the pilot and in special cases the human team constituting the flight crew. Of course, the concept of the human factor should be defined here more widely. A man has a direct influence on a number of determinants, such as e.g. construction, use and handling of the aircraft, management of continuous airworthiness or management of aviation organizations. In this context, the determining influence of man can be seen both in the area of technical factors, whose role as causes of air accidents is currently decreasing, as well as in the area of organizational factors that currently dominate among the causative factors of aviation events. The classic components of the human factor as an element having a key impact on the performance of the aerial task are: [13]: 
- psychophysical condition of the crew / pilot (state of health, rest),

- air training level,

- individual predispositions of crew members, including resistance to stressful situations,

- aviation experience,

- discipline understood as the ability to understand and comply with aviation regulations and restrictions imposed by regulations and instructions,

- $\quad$ susceptibility to the negative impact of external factors, etc.

In the context of the above, the human factors included in the system classification should be mentioned, i.e. not resulting directly from the pilot's action but from the influence of system environment elements on it. The main systemic (organizational) factors affecting flight safety can be included here:

- applicable aviation regulations and instructions,

- the internal procedures of the aviation organization,

- $\quad$ scope and complexity of performed tasks,

- logistics and technical security of aviation operations,

- strict implementation of training programs,

- $\quad$ proper air traffic control,

- free access to a variety of navigational aids,

- work atmosphere and interpersonal relations,

- other factors depending on the nature and specificity of the aviation organization.

A very wide range of determining factors results in multiple possibilities of impact on the safety of aviation tasks. The features of the described factors predestine them for direct impact on humans, so one can notice a direct coupling of systemic factors with the human factor. It is worth noting here that the environmental factor through its indirect impact is difficult to identify as the primary (main) source of the accident. Meanwhile, it can occupy a very important place among other factors. Effective impact on the human factor is extremely difficult. It is not enough to have theoretical knowledge and ambition - a long-term practice and imagination are indispensable. It is only the air operator fulfilling these features that can effectively counteract the negative impact of the broadly understood human factor. This also applies to the proper identification of the human factor as the source of an aircraft accident.

\section{Pilot error and non-compliance}

The most frequently indicated causes of aviation events include the error in piloting technology [8]. In the general sense, the mistake in piloting technique results from the fact that a person in a system with an aircraft is his weakest link, susceptible to committing a mistake (s). In each flight, a pilot team (crew) works on a team specific to aviation, and harmful to humans, external factors. They affect directly on the pilot's body, and indirectly on his ability to perform tasks. In these abnormal conditions, he accomplishes his tasks. They are most often complicated, requiring a continuous collection of incoming information, evaluation, and analysis of the current situation, rapid adoption and implementation of the right decision in the given circumstances. The pilot acting in conditions significantly different from those to which man has adapted for millions of years, by nature makes mistakes, that is, acts contrary to the previously established plan, and even possessed knowledge. Depending on physiological, psychophysical characteristics, abilities, training, and habits, the pilot may make more or fewer mistakes. They can eliminate them at the initial stage of their formation or fail to notice them (limitations in perception) in time, lead to a critical situation in terms of security. An error is, therefore, an inseparable attribute of human activity, though undoubtedly undesirable. 
To sum up, the pilot's mistake is an unintentional, accidental (inadvertent) action (or lack thereof) caused by the failure to collect information necessary for the given action. Pilot error can lead to deviations from the prescribed flight conditions that threaten its safety. The imperfection of man is first of all the fact that he is not able to precisely assess the threats (take into account all of his factors) in the complex nature of his actions with the simultaneous impact of many different external factors on him. The counterbalance to the pilot error indicated above is a violation of aviation regulations, the violation of which directly leads to an accident. Usually, it is intentional. In these circumstances, the pilot, in violation of aviation regulations, agrees or should accept the risk of any breach. In connection with his professional preparation and practice, he should be aware of the effects of such action. Of course, there may also be a situation when there is a breach of regulations that do not result in an accident and constitutes an infringement in itself, usually penalized in the provisions of the Aviation Law.

\section{Indication of the causes of the accident}

The classification of causes of aviation accidents discussed in the previous subsections has been systematically classified. It should be noted, however, that the degree of influence of these factors on the occurrence of an accident may differ. Bearing in mind the above, the differentiation of the cause of an aircraft accident can be classified as follows:

- direct cause - a fact, phenomenon or factor that directly caused an accident,

- main cause - a factor, phenomenon or action that essentially contributed to the accident, without which an emergency situation could not arise, and therefore a direct cause,

- favorable cause - externalization of the links between the cause and effect chain, which constitute a real transformation of possibilities into a real threat of an aviation accident.

In the context of the above reasons, it is also possible to define the boundary of inevitability as a boundary in the cause-and-effect chain, beyond which an accident must occur. Defined causes of accidents may be used in preparatory and court proceedings. The above-mentioned causes of the accident are of general nature. In preparatory proceedings related to an aviation accident, the causes should be considered very individually. It is worth noting here that there may be several independent main causes, each of which in the downstream chain of events may lead to an accident. A similar property has also favorable reasons defined here. In special cases, there may also be a situation where the main cause is also a direct cause. It may also happen that favorable causes will not exist, and the main and immediate cause is only the occurrence of an accident.

At the same time, it is crucial to assess whether the accident is the result of a violation of the Aviation Law, executive provisions, instructions and resulting from a conscious infringement or is a mistake, and the action of the crew (pilot) is unintentional. External factors that are completely independent of human activities must also be taken into account regardless of the system in which it operates, including in particular the pilot (crew) and the authorities securing the flights. These causes have the characteristic feature that none of the identifiable aviation systems has an effective impact on the occurrence of an event and its effects. A schematic diagram of the preliminary division of the causes of an aviation accident into the needs of the preparatory proceedings is illustrated in Fig. 4. 


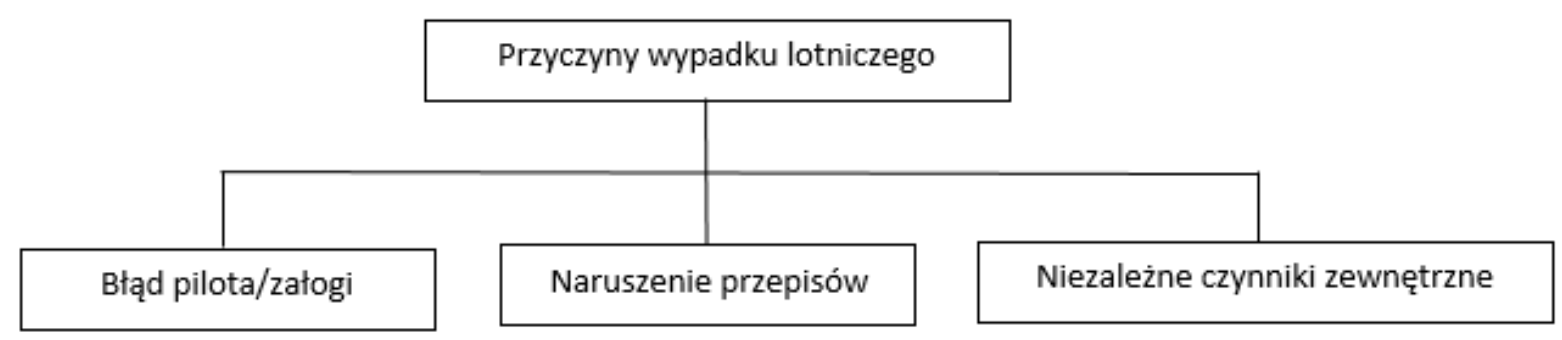

4. Initial division of the causes of the accident during the pre-trial investigation

\section{Summary}

The rather brief analysis of the causes of aviation accidents in the article indicates their high complexity. At the same time, it indicates the dominant influence of the human factor among these causes. This factor, however, is not homogeneous in its sources and origin. In conducted proceedings, it is reasonable to determine the possible influence of persons on the occurrence of an event, an indication of the main and direct cause and favorable reasons. Due to the complex and highly specialized nature of these phenomena, these activities should be entrusted to specialists - public experts and experts in the field of aviation. At this point, it also seems to be an extremely important training in dealing with the essence of issues regarding the causes of aviation events. This will allow them in cooperation with experts to properly assess the causes of events, and in particular to identify the intentional actions of members of crews of aircraft and other persons associated with the aviation system. This will enable further determination of the extent of their possible guilt for the occurrence of an accident or indication of a different reason.

\section{Source materials}

[1] Aspekty prawne badania zdarzeń lotniczych w świetle Rozporządzenia 996/2010. Praca zbiorowa pod redakcją A. Konert. Oficyna Wydawnicza Uczelni Łazarskiego. Warszawa, 2013.

[2] Badanie wypadków i incydentów statków powietrznych. Załącznik 13 do Konwencji o międzynarodowym lotnictwie cywilnym. Wydanie dziesiąte Lipiec 2010. Organizacja Międzynarodowego Lotnictwa Cywilnego.

[3] Beaty D. Pilot naga prawda. Czynnik ludzki w katastrofach lotniczych. Ewertowski, T. Czynności badawcze ekspertów na miejscu wypadków lotniczych. Materiały konferencji: Katastrofy i wyjaśnienie ich przyczyn w ujęciu procesowym i kryminalistycznym. Warszawa: marzec 2015 rok.

[4] Chruzik. K., Fellner A. Analyze sources of threats determining aviation events in 2015. Str. 71-82. International conference SimSchool 2017. Application of simulators in aviation specialists training. Let's Fly s.r.o. Ostrawa,_ISBN 978-80-270-2104-8.

[5] Informacja o zdarzeniach w lotnictwie cywilnym w 2010 roku. Wydział Analiz i Statystyki Bezpieczeństwa Lotów ULC. Prezentacja na dorocznej konferencji bezpieczeństwa w lotnictwie cywilnym.

[6] Instrukcja Bezpieczeństwa Lotów Lotnictwa Sił Zbrojnych Rzeczypospolitej Polskiej WLOP 346/2004.

[7] Karsznicki, K. Aspekty prawne badania wypadków lotniczych w kontekście prowadzonego postępowania karnego. Warszawa: Prokuratura i Prawo. 10/2012.

[8] Klich, E. Bezpieczeństwo lotów. Wypadki, przyczyny, profilaktyka. Puławy, 1998.

[9] Konieczka R. General methodology of the activities undertaken by the authorities investigating aviation occurrences. Str. 102-109. International conference SimSchool 
2017. Application of simulators in aviation specialists training. Let's Fly s.r.o. Ostrawa,_ISBN 978-80-270-2104-8.

[10] Konieczka R. How To Secure Basic Evidence After An Aviation Accident. Scientific Journal of Silesian University of Technology. Series Transport. 2017, 94, 65-74. ISSN: 0209-3324.

[11] Konieczka R. Lotnictwo jako specyficzna dziedzina opiniowania przez biegłego sądowego. Problemy Kryminalistyki 2902015.

[12] Konieczka R. Potencjalne zagrożenia podczas wykonywania oględzin miejsca wypadku lotniczego. Problemy Kryminalistyki 289(3) 2015.

[13] Konieczka R. Żurek P. Dominujący wpływ czynnika ludzkiego na bezpieczeństwo wykonywania lotów. Biuletyn Centralnego Ośrodka Szkolenia Straży Granicznej. Koszalin 1/2010.

[14] Konieczka, R.: The danger for people and the environment related to a plane crash. Presentation. Transport problems. VI International Scientific Conference. Katowice 27.06.2014 r.

[15] Podstawy organizacji i metodyki badania wypadków lotniczych w lotnictwie cywilnym RP Praca zbiorowa pod redakcją A. Milkiewicza. Warszawa 2001.

[16] Rozporządzenie Ministra Infrastruktury z dnia 18 stycznia 2007 r. W sprawie wypadków i incydentów lotniczych (Dz. U. 2003 r. Nr 35 poz. 225).

[17] Rozporządzenie Parlamentu Europejskiego i Rady UE nr 996/2010 w sprawie badania wypadków i incydentów w lotnictwie cywilnym oraz zapobiegania im oraz uchylające dyrektywę 94/56/W.

[18] Ustawa z dnia 3 lipca 2002 r. Prawo Lotnicze (Dz. U. 2002 r. Nr 130 poz. 1112). Tekst jednolity - obwieszczenie Marszałka Sejmu Rzeczpospolitej Polskiej z dnia 13 września 2013 r. w sprawie ogłoszenia jednolitego tekstu ustawy - Prawo Lotnicze, Dziennik Ustaw Rzeczypospolitej Polskiej z 28 listopada 2013 r., poz. 1393. 